\title{
Corrigenda in the Tanzil.net Uthmani Text
}

Version 1.1: Release date: February 12, 2021

http://tanzil.net/updates/

Text Updates

All Texts:

- Three occurrences of بَ in ayas 2:181, 8:6, and 13:37 are replaced by Lبنَ.

Uthmani:

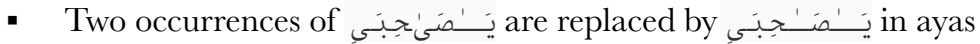
12:39 and 12:41 to match Medina Mushaf.

- HIGH_NOON (U+06E8) is replaced by TATWEEL + HIGH_NOON in the word نُ ن in aya 21:88.

- SMALL_WAW (U+06E5) is replaced by TATWEEL + SMALL_WAW in the word 1 in ay in 17:7.

- SMALL_YEH (U+06E6) in the middle of words are replaced by TATWEEL + HIGH_YEH (U+06E7), e.g. in

- All occurrences of 1 \& $\mathrm{J}$ are replaced by

Uthmani Minimal:

- Capital Yeh's before Hamza (e.g. in شَيء) are replaced by dotless Yeh (ى) to remain compatible with Medina Mushaf.

Simple:

- The following changes are made to increase compatibility with

Uthmani text:

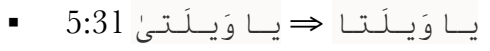

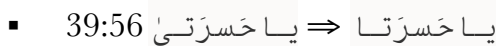

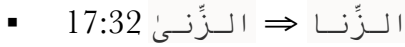

